\title{
DAMPAK OVERCAPACITY TERHADAP TINGKAT STATUS GIZI NARAPIDANA
}

\author{
Faiz Fakhri Isjwara \\ Prodi Teknik Pemasyarakatan, Politeknik Ilmu Pemasyarakatan \\ Jalan Raya Gandul No.4 Cinere-Kota Depok 16512 \\ Email :faizfakhriisjwaraa@gmail.com
}

\begin{abstract}
The principle of the organization of prisons (Lembaga Pemasyarakatan/ LAPAS) must prioritize a humane approach so that prisoners and prisoners receive their rights. If the implementation is good, the objective of LAPAS is to carry out social reintegration, namely the restoration of the unity of life, life and livelihood of prisoners and correctional students both prisoners as individuals, social beings and God's creatures with society can be achieved. However, this organization faces obstacles, namely the problem of overcapacity. This can have implications for suboptimal and can even lead to failure to function as a correctional institution. The problem of over capacity will also have an impact on the health conditions of prisoners. Sleep conditions, eating patterns, health services that are less than the maximum due to over capacity will certainly have a negative impact on the nutritional status of prisoners. This study aims to determine the impact of Overcapacity Impacts on the Nutritional Status Level of Prisoners in Class II A Penitentiary, Sidoarjo. This type of research is a quantitative correlational analytic survey with a cross-sectional design. The number of samples was 91 inmates. The sampling technique is by random sampling. Data is collected by weighing body weight and height and comparing with ideal body weight. The results showed that the more overcapacity, the nutritional status of prisoners decreased. Room conditions can affect the provision of an unbalanced diet. Thus, that this causes the prisoners to experience malnutrition.
\end{abstract}

Keywords : Prisoners, Overcapacity, Nutrition Status, Nutrition Status, Correctional Institution

\begin{abstract}
ABSTRAK
Prinsip penyelenggaraan lembaga pemasyarakatan (LAPAS) harus mengedepankan pendekatan manusiawi sehingga para tahanan dan narapidana memperoleh hak-haknya. Apabila penyelenggaraan baik maka tujuan dari LAPAS yaitu melakukan reintegrasi sosial yaitu membaiknya kesatuan hubungan hidup, kehidupan dan penghidupan narapidana dan anak didik pemasyarakatan baik narapidana sebagai individu, mahkluk sosial dan mahkluk Tuhan dengan masyarakat dapat tercapai. Namun penyelenggaraan tersebut menghadapi hambatan yaitu permasalahan over capacity. Hal tersebut dapat berakibat pada rendahnya keoptimuman bahkan bisa mengarah pada kegagalan fungsi sebagai lembaga pemasyarakatan. Permasalahan over capacity juga akan berdampak pada kondisi kesehatan dari para narapidana. Kondisi tidur, pola makan, layanan kesehatan yang kurang maksimal yang diakibatkan oleh over capacity tentunya akan berdampak negative pada status gizi para narapidanan. Penelitian ini bertujuan untuk mengetahui dampak Dampak Overcapacity Terhadap Tingkat Status Gizi Narapidana Di Lembaga Pemasyarakatan Kelas II A Sidoarjo. Jenis penelitian ini ialah survei analitik quantitative korelasional dengan desain crosectional. Jumlah sampel sebesar 91 narapidana. Teknik pengambilan sampel dengan cara random sampling. Data dikumpulkan dengan cara menimbang berat badan dan tinggi badan serta membandingkan dengan berat bada ideal. Hasil penelitian menunjukkan bahwa semakin overcapacity maka status gizi narapidana semakin menurun. Kondisi ruangan yang pada dapat mempengaruhi pemberian menu makanan yang tidak seimbang. Sehingga hal ini menyebabkan para narapidana mengalami gizi buruk.
\end{abstract}

Kata Kunci : Narapidana, Overcapacity Tingkat Status Gizi Status Gizi, Lembaga Pemasyarakatan 


\section{PENDAHULUAN}

\section{Latar Belakang (Opsional)}

Sistem penjara mencakup prinsip membina narapidana dengan pendekatan yang lebih manusiawi, tercermin dalam upaya membina narapidana dan mahasiswa pemasyarakatan berdasarkan sistem pemasyarakatan yang ditentukan dalam Undang-Undang No. 12 tahun 1995 dalam konteks menjadi manusia sepenuhnya. Ini berarti bahwa pembinaan mengembalikan upaya untuk merealisasikan reintegrasi sosial, yakni pemulihan kehidupan dan hubungan antara kehidupan dan mata pencaharian narapidana dan peserta didik pemasyarakatan yang mana selain narapidananya yang memiliki hak juga sebagai makhluk sosial serta makhluk tuhan dengan masyarakat. ${ }^{(1)}$

Prinsip pembinaan yang diatur dalam sistem pemasyarakatan dapat mengandung arti baik secara filosofis maupun sosiologis. Secara filosofis, paradigma pemasyarakatan mempunyai asumsi bahwa manusia (termasuk narapidana) adalah mahkluk social, ia secara naluriah mempunyai kebutuhan untuk selalu berhubungan dengan masyarakat. ${ }^{(2)}$

Ada beberapa faktor memiliki pengaruh besar terhadap kinerja sebuah penjara dalam melakukan layanan pemasyarakatan, yaitu kuantitas dan kualitas layanan penjara, fasilitas dan infrastruktur yang memadai, program pelatihan yang disesuaikan dengan minat dan bakat, dan keberadaan komparatif. Beberapa faktor di atas sangat erat kaitannya. Akan tetapi yang bisa diamati adalah bahwasannya dalam tujuan dan pola membimbing tahanan menghadapi banyak kendala dan keterkaitannya pada suboptimal, bahkan bisa menyebabkan kegagalan sebagai lembaga pemasyarakatan. Salah satu hambatan tersebut adalah yaitu over capacity atau kelebihan kapasitas dan telah menjadi isu nasional dimana

\footnotetext{
${ }^{1}$ Angkasa, “Over capacity narapidana di Lembaga permasyarakatan, faktor penyebab, implikasi negatif, serta solusi dalam upaya optimalisasi pembinaan narapidan, Jurnal Dinamika Hukum, Vol. 10 No. 3 (2010).

2 Harmidi, Budi. Pembinaan Narapidana sebagai upaya untuk mewujudkan tujuan pembinaan (studi kasus di lembaga pemasyarakatan Magelang). Semarang: Universitas Diponegoro.
}

perbandingan antara kapasitas ruang hunian dengan jumlah penghuni sudah sangat jauh. Namun, kebijakan pemerintah khususnya Direktorat Jenderal Pemasyarakatan dalam mengatasi permasalahan overcapacity atau kelebihan kapasitas. ${ }^{(3)}$

Tingkat hunian Narapidana secara nasional pada tahun tahun 2020 mayoritas mengalami overcapacity. Jumlah penghuni LAPAS dari 33 kntor wilayah pada tahun 2020 mencapai 271,206 orang dengan kapasitas seharusnya 131,931 orang atau over capacity sebesar 206\%. Sedangkan dari total 524 LAPAS dari 33 kantor wilayah terdapat 419 LAPAS dengan status Overcapacity sedangkan sisanya 105 tidak melibihi kapasitas. ${ }^{(4)}$

Masalah over kapasitas pada dasarnya akan memperburuk kondisi di dalam Lembaga Pemasyarakatan yang cenderung menyebabkan timbulnya ketegangan-ketegangan (tensions) yang dikatakan sebagai "pains of imprisonment" (derita yang diakibatkan pemenjaraan). Gresham Sykes mengemukakan tentang wujud derita itu, yaitu : (Sykes, 1997:447) 1. Kehilangan kebebasan bergerak (deprivation of liberty) 2. Kehilangan hak untuk memiliki barang pribadi dan pelayanan (deprivation of goods and services) 3 . Kehilangan kebebasan berhubungan dengan lawan jenis (deprivation of heterosexual relationship) 4. Kehilangan kebebasan menentukan kehendak (deprivation of autonomy) 5. Kehilangan rasa aman (deprivation of security)."

Problema kapasitas berlebih tersebut dialami oleh Lembaga Pemasyarakatan Kelas IIA Sidoarjo. Lapas Kelas IIA Sidoarjo ialah unit pelaksana teknis pemasyarakatan di wilayah Jawa Timur yang kapasitas warga binaannya berjumlah 350 orang, namun Lapas Kelas IIA Sidoarjo telah menampung 1167 orang pada bulan maret 2020. Dari data di atas dapat kita tahu bahwasannya Lapas Kelas IIA Sidoarjo mengalami over capacity sebesar $233 \%$. Hal

\footnotetext{
${ }^{3}$ CDS, Realitas penajara Indonesia 2: Survei kualitas layanan pemasyarakat (wilayah Aceh, Bandung, Nusa Kambangan dan Semarang), Jakarta.

${ }^{4}$ Anwar, yesmil, dan Adang. Pembaruan Hukum Pidana, Reformasi Hukum Pidana. Jakarta Grasindo.
} 
tersebut dapat memberikan dampak pada kinerja pemasyarakatan Lapas kelas IIA Sidoarjo, yakni ketidaksesuaian konsepnya dengan aturan yang termaktub di dalam Undang-Undang Nomor 12 Tahun 1995 tentang Pemasyarakatan.

Table 1. data jumlah tahanan, kapasitas dan over kapasitas

\begin{tabular}{|l|l|c|c|c|c|}
\hline $\begin{array}{c}\text { N } \\
\text { o }\end{array}$ & Periode & $\begin{array}{c}\text { Tahan } \\
\text { an \& } \\
\text { Napi }\end{array}$ & $\begin{array}{c}\text { Kapa } \\
\text { sitas }\end{array}$ & $\begin{array}{c}\% \\
\text { Over } \\
\text { Kapasi } \\
\text { tas }\end{array}$ \\
\hline 1 & Januari & 1062 & 350 & 303 & 203 \\
\hline 2 & Februari & 1093 & 350 & 312 & 212 \\
\hline 3 & Maret & 1089 & 350 & 311 & 211 \\
\hline 4 & April & 1139 & 350 & 325 & 225 \\
\hline 5 & Mei & 1195 & 350 & 341 & 241 \\
\hline 6 & Juni & 1212 & 350 & 346 & 246 \\
\hline 7 & Juli & 1160 & 350 & 331 & 231 \\
\hline 8 & Agustus & 1114 & 350 & 318 & 218 \\
\hline 9 & $\begin{array}{l}\text { Septemb } \\
\text { er }\end{array}$ & 1131 & 350 & 323 & 223 \\
\hline 1 & $\begin{array}{l}\text { Oktober } \\
0\end{array}$ & 1148 & 350 & 328 & 228 \\
\hline 1 & $\begin{array}{l}\text { Nopemb } \\
\text { er }\end{array}$ & 1167 & 350 & 333 & 233 \\
\hline 1 & $\begin{array}{l}\text { Desembe } \\
\text { r }\end{array}$ & 1167 & 350 & 333 & 233 \\
\hline
\end{tabular}

Hak-hak sebagai inidividu juga melekat pada setiap Narapidana, yang mana hak-hak tersebut juga berhak mereka dapatkan. Hak untuk mendapat layanan kesehatan salah satunya, selain itu juga hak untuk menerima makanan layak konsumsi yang sesuai sehingga tetap terjaga dan terjamin kesehatannya. Permasalahan over capacity juga akan berdampak pada kondisi kesehatan dari para narapidana. Kondisi tidur, pola makan, layanan kesehatan yang kurang maksimal yang diakibatkan oleh over capacity tentunya akan berdampak negative pada status gizi para narapidanan. ${ }^{(5)}$

\footnotetext{
${ }^{5}$ Selalahi, Jansen. Makanan Fungsional.

Yogyakarta: Kanisius. 2005

${ }^{6}$ Sherwood Lauralee. Susunan saraf pusat. In: Yesdelita N, editor. Fisiologi Manusia dari Sel ke Sistem (6th ed). Jakarta: EGC, 2011; p. 182

${ }^{7}$ Haryono A, Rindiarti A, Arianti A, Pratiwi A, Ushuluddin A, Setiawati A, et al, Dept IImu Kesehatan Anak FKUIRSCM. Prevalensi gangguan
}

Salah satu penyebab tidak seimbangnya gizi seseorang yaitu karna durasi tidur yang tak maksimal disebabkan terhambatnya nafsu makan serta produksi hormon yang berubah. ${ }^{(6)}$

Mikronutrien berperan penting terhadap tidur karena efek pada sistem neurobiologik, seperti vitamin B, besi, kalsium dan magnesium. Zat-zat gizi tersebut dapat memberikan efek promotif pada tidur sedangkan asupan yang tidak adekuat dapat menyebabkan gangguan tidur. ${ }^{(7)}$

\section{METODE PENELITIAN}

Jenis penelitian ini ialah survei analitik quantitative korelasional dengan desain crosectional. Lokasi pelaksanaan penelitian di Lembaga Pemasyarakatan Kelas II A Sidoarjo. Penelitian dilaksanakan pada 1 Maret 2020 Pemelihan lokasi di dasarkan pada data bahwa terjadi peningkatan over kapasitas setiap tahunnya.

Dari keseluruhan jumlah populasi, dihitung jumlah sampel dengan menggunakan rumus slovin. Dari 1167 populasi penelitian maka didapat sampel penelitian sebesar Jumlah sampel sebesar 91 narapidana. Teknik pengambilan sampel dengan cara random sampling.

Penilaian status gizi dilakukan dengan mengukur tinggi badan menggunakan mikrotoa dan pengukuran berat badan menggunakan timbangan. Berdasarkan tinggi badan dan berat badan dinilai status gizi menggunakan rasio IMT merupakan rasio berat badan $(\mathrm{Kg})$ dan tinggi badan $\left(\mathrm{m}^{2}\right)$ seseorang. Indikator ini digunakan pada orang dewasa $>18$ tahun untuk melihat apakah orang tersebut memiliki kekurangan atau kelebihan berat badan. Penilaian over kapasitas dilakukan dengan cara membagi jumlah penghuni dengan kapasitas kamar yang ada apabila ternyata jumlah penghuni lebih tinggi dengan kapasitas kamar maka dapat di pastikan terdapat over kapasitas. ${ }^{(8)}$ Analisis data yang digunakan dalam penelitian ini adalah Analisis statistik parametric dengan menggunakan regresi

tidur pada remaja usia 12-15 tahun di sekolah lanjutan tingkat pertama. Sari Pediatri. 2009;11: 149-54.

${ }^{8}$ Angkasa. "Over Capacity Narapidana di Lembaga Pemasyarakatan, Faktor Penyebab, Implikasi Negatif, Serta Solusi dalam Upaya Optimalisasi Pembinaan Narapidana", Jurnal Dinamika Hukum, Vol. 10 No. 3, (2010) 
sederhana. Analisis regresi digunakan guna mengetahui dampak atau pengaruh dampak overcapacity terhadap tingkat status gizi narapidana.

\section{Hasil dan Pembahasan \\ Karakteristik Responden}

Tabel 2. Karakteristik responden

\begin{tabular}{|l|c|c|c|}
\hline \multicolumn{2}{|l|}{ Jenis Kelamin } & Jumlah & Persentase \\
\hline 1 & Laki-Laki & 91 & $100 \%$ \\
\hline 2 & Perempuan & 0 & $0 \%$ \\
\hline \multicolumn{2}{|l|}{ Usia } & Jumlah & Persentase \\
\hline 1 & $>21$ tahun & 5 & $5 \%$ \\
\hline 2 & $21-30$ tahun & 34 & $37 \%$ \\
\hline 3 & $31-40$ tahun & 32 & $35 \%$ \\
\hline 4 & $41-50$ tahun & 12 & $13 \%$ \\
\hline 5 & $>50$ tahun & 8 & $9 \%$ \\
\hline \multicolumn{2}{|l|}{ Masa Hukuman } & Jumlah & Persentase \\
\hline 1 & $<1$ tahun & 5 & $5 \%$ \\
\hline 2 & $1-5$ tahun & 69 & $76 \%$ \\
\hline 3 & $>5$ tahun & 17 & $19 \%$ \\
\hline \multicolumn{2}{|l|}{ Status Hukum } & Jumlah & Persentase \\
\hline
\end{tabular} \mid \begin{tabular}{l} 
Tahanan \\
\hline
\end{tabular}

Hasil penelitian menunjukkan bahwa karakteristik responden berdasarkan jenis kelamin 91 orang atau $100 \%$ dari respoden lakilaki. Karakteristik responden berdasarkan usia terdapat 5 responden atau $5 \%$ yaitu usia $>21$ tahun, 34 responden atau $37 \%$ yaitu dengan usia 21-30 tahun, 32 responden atu 35\% pada usia 31-40 tahun, sedangkan usia 41-50 tahun terdapat 12 responden atau $13 \%$ dan usia $>50$ tahun terdapat 8 responden atau $9 \%$. Karakteristik responden berdasarkan masa hukuman terdapat 5 responden atau $5 \%$ memiliki masa hukuman <1 tahun, masa tahanan 1-5 tahun terdapat 69 responden atau $76 \%$, dan $>5$ tahun terdapat 17 responden atau $19 \%$. Status hukuman masa tahanan terdapat 5 responden atau 5\%, dan narapidana terdapat 86 responden dengan $95 \%$.

\section{Indek Massa Tubuh}

Tabel 3. Indek Massa Tubuh para Narapidana

\begin{tabular}{|c|c|c|c|c|}
\hline $\begin{array}{l}\mathrm{N} \\
\mathrm{O}\end{array}$ & IMT & $\begin{array}{l}\text { Status } \\
\text { Gizi }\end{array}$ & $\begin{array}{l}\text { Jumla } \\
\mathrm{h}\end{array}$ & $\begin{array}{l}\text { Persentas } \\
\mathrm{e}\end{array}$ \\
\hline 1 & $<18.5$ & $\begin{array}{l}\text { Gizi } \\
\text { Kuran } \\
\mathrm{g}\end{array}$ & 29 & $32 \%$ \\
\hline 2 & $\begin{array}{l}18.5- \\
25\end{array}$ & $\begin{array}{l}\text { Gizi } \\
\text { Baik }\end{array}$ & 53 & $58 \%$ \\
\hline 3 & $>25$ & $\begin{array}{l}\text { Gizi } \\
\text { Lebih }\end{array}$ & 9 & $10 \%$ \\
\hline \multicolumn{3}{|c|}{ Jumlah } & 91 & $100 \%$ \\
\hline
\end{tabular}

Sumber: Data diolah peneliti

Hasil penelitain menunjukkan 29 responden atau 32\% memiliki indek masa tubuh $<18,5$ dan memiliki status gizi kurang. Terdapat 53 responden atau $58 \%$ memiliki indek masa tubuh 18,5-25 dengan status gizi baik, dan 9 responden atau 10\% memiliki indek masa tubuh $>25$ memiliki status gizi lebih. Hasil penelitian menunjukkan bahwa responden pada lapas laki-laki diapatkan status gizi pada responden dalam status gizi yang baik.

Tabel 4. Hasil status kapasitas sel

\begin{tabular}{|c|c|c|c|c|}
\hline No & $\begin{array}{l}\text { Status } \\
\text { Kapasitas } \\
\text { Sel }\end{array}$ & Kategori & Jumlah & Persentase \\
\hline 1 & $<100 \%$ & $\begin{array}{l}\text { Kapasitas } \\
\text { Kurang }\end{array}$ & 6 & $7 \%$ \\
\hline 2 & $100 \%$ & $\begin{array}{l}\text { Sesuai } \\
\text { Kapasitas }\end{array}$ & 5 & $5 \%$ \\
\hline 3 & $\begin{array}{l}101 \%- \\
200 \%\end{array}$ & $\begin{array}{l}\text { Over } \\
\text { Kapasitas } \\
\text { Ringan }\end{array}$ & 18 & $20 \%$ \\
\hline 4 & $>200 \%$ & $\begin{array}{l}\text { Over } \\
\text { Kapasitas } \\
\text { Berat } \\
\end{array}$ & 62 & $68 \%$ \\
\hline \multicolumn{3}{|c|}{ Jumlah } & 91 & $100 \%$ \\
\hline
\end{tabular}

Sumber: Data diolah peneliti

Hasil penelitian menunjukkan nilai responden pada status kapasitas sel, terdapat 6 responden atau $7 \%$ berada didalam kapasitas sel < 100\% dalam kategori kapasitas kurang , 5 responden atau 5\% dalam kapasitas $100 \%$ dan masuk dalam category sesuai dengan kapasita, 18 responden atau $20 \%$ dalam status kapasitas sel 101-200\% dalam kategori over kapasitas ringan, dan 62 responden atau 68\% dalam 
status kapasitas sel > 200\% dan pada category over kapasitas berat.

Tabel 5. Hasil uji statistic over kapasitas pada status gizi 


\begin{tabular}{|c|c|c|c|c|c|}
\hline \multirow[b]{2}{*}{$\begin{array}{l}\mathrm{N} \\
\mathrm{O}\end{array}$} & \multirow{2}{*}{$\begin{array}{c}\text { Status } \\
\text { Over } \\
\text { Kapasita } \\
\text { s }\end{array}$} & \multicolumn{3}{|c|}{ STATUS GIZI } & \multirow[b]{2}{*}{$\begin{array}{c}\text { Tota } \\
1\end{array}$} \\
\hline & & $\begin{array}{l}\text { Gizi } \\
\text { Kuran } \\
\text { g }\end{array}$ & $\begin{array}{l}\text { Gizi } \\
\text { Bai } \\
\mathrm{k}\end{array}$ & $\begin{array}{l}\text { Gizi } \\
\text { Lebi } \\
\text { h }\end{array}$ & \\
\hline 1 & $\begin{array}{l}\text { Kapasita } \\
\text { s Kurang }\end{array}$ & 0 & 2 & 4 & 6 \\
\hline 2 & $\begin{array}{l}\text { Sesuai } \\
\text { Kapasita } \\
\text { s }\end{array}$ & 1 & 4 & 0 & 5 \\
\hline 3 & $\begin{array}{l}\text { Over } \\
\text { Kapasita } \\
\text { s Ringan }\end{array}$ & 3 & 13 & 2 & 18 \\
\hline 4 & $\begin{array}{l}\text { Over } \\
\text { Kapasita } \\
\text { s Berat }\end{array}$ & 25 & 34 & 3 & 62 \\
\hline & Total & 29 & 53 & 9 & 91 \\
\hline
\end{tabular}

Hasil penelitian menunjukkan bahwa gambar titik yang ada menjauhi garis yang menunjukkan bahwa adanya pengaruh yang berbeda nyata terhadap status gizi para penghuni lapas.

Hasil penelitian menunjukkan nilai responden pada status gizi dalam kategori kapasitas kurannn terdapat 2 responden pada gizi baik dan 4 dalam gizi baik, pada sesuai kapasitas terdapat 1 responden memiliki gizi kurang, 4 responden gizi baik dan tidak ada

\section{Analisis Regresi}

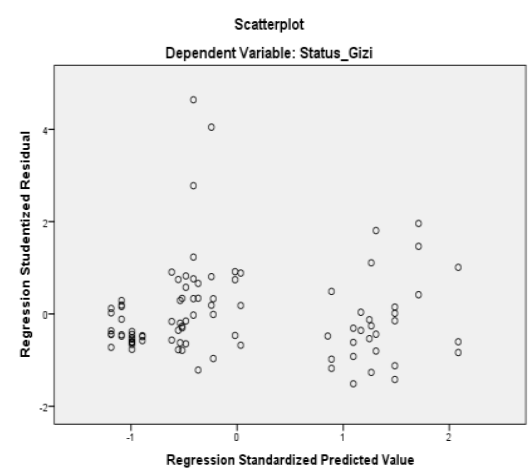

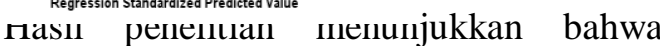
terdapat pengaruh dari status gizi di lapas, gambar diatas menunjukkan bahwa semua titik tersebar yang menunjukkan adanya terdapat pengaruh. responden lapas yang memiliki gizi lebih, dalam kapasitas over ringan terdapat 25 gizi kurang, 34 gizi baik, dan 3 responden dalam kategori gizi lebih, dan status kapasita berat terdapat 29 gizi kurang, 53 responden gizi baik dan 9 responden gizi lebih.

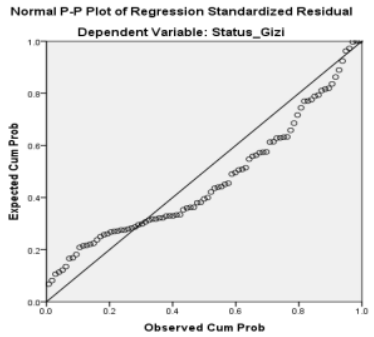

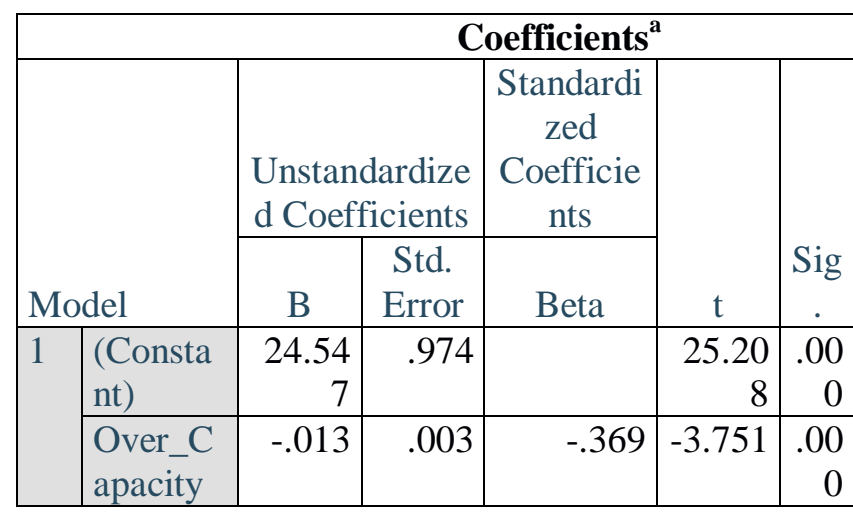

a. Dependent Variable: Status_Gizi

Hasil penelitian menunjukkan bahwa rerata kondisi over capacity di lapas dapat mempengaruhi status gizi para narapidana. Hasi uji regresi sederhana dengan uji sampel t test terdapat nilai t 25.208 lebih besar dari t tabel dengan nilai signiifkansi 0.000 lebih kecil 0,05. Hal ini menunjukkan bahwa kondisi lapas yang semaket penuh atau over capacity maka status gizi para narapidana akan semakin menurun.

\begin{tabular}{|l|c|r|r|c|}
\hline \multicolumn{5}{|c|}{ Model Summary $^{\mathbf{b}}$} \\
\hline Model & $\mathrm{R}$ & R Square & $\begin{array}{r}\text { Adjusted } \\
\text { R Square }\end{array}$ & $\begin{array}{c}\text { Std. Error } \\
\text { of the } \\
\text { Estimate }\end{array}$ \\
\hline 1 & $.369^{\mathrm{a}}$ & .137 & .127 & 3.58293 \\
\hline
\end{tabular}

a. Predictors: (Constant), Over_Capacity

b. Dependent Variable: Status_Gizi

Hasil uji statistic menunjukkan hubungan over capacity dengan status gizi narapidana yang ada dilapas didapatkan nilai koefisien korelasi (r) 0,369 maka dapat diinterprestasikan memiliki kekauatan hubungan yang erat dengan orientasi 
hubungan positif yang artinya tinggi capacity maka komsumsi juga semakin rendah sehingga status gizi narapidana akan semakin berkurang.

\section{KESIMPULAN}

1. Sebagaian narapidana yang berada dicapasity over ringan didapatkan narapidana yang masih dalam kategori gizi baik

2. Narapidana yang berdada di capacity over berat terdapat narapidana kurang baik namun untuk narapidana yang berada dikategori status gizi yang tidak baik

3. Semakin over capacity maka status gizi narapidan semakin menurun

\section{SARAN}

1. Bagi lembaga permasyarakatan perlu dilakukan tindakan adanya variasi dalam pemberian menu makan

2. Perlu adanya pengurangan dan pembagian ruangan dengan jumlah yang normal

\section{DAFTAR PUSTAKA}

1. Angkasa, "Over capacity narapidana di Lembaga permasyarakatan, faktor penyebab, implikasi negatif, serta solusi dalam upaya optimalisasi pembinaan narapidan, Jurnal Dinamika Hukum, Vol. 10 No. 3 (2010).

2. Hermidi, Budi and Sularto, RB. (2011). Pembinaan narapidana sebagai upaya untuk mewujudkan tujuan pembinaan (Studi Kasus Dilembaga Pemasyarakatan Magelang). Documentation. Fakultas Ilmu Hukum.

3. CDS, 2014, Realitas Penjara Indonesia 2: Survei Kualitas Layanan Pemasyarakatan (Wilayah Aceh, Bandung, Nusa Kambangan dan Semarang), Jakarta.

4. Anwar, Yesmil, dan Adang, 2008, Pembaruan Hukum Pidana, Reformasi Hukum Pidana. Jakarta: Grasindo

5. Selalahi, Jansen. Makanan Fungsional. Yogyakarta: Kanisius. 2005.

6. Sherwood Lauralee. Susunan saraf pusat. In: Yesdelita N, editor. Fisiologi Manusia dari Sel ke Sistem (6th ed). Jakarta: EGC, 2011; p. 182

7. Haryono A, Rindiarti A, Arianti A, Pratiwi A, Ushuluddin A, Setiawati A, et al, Dept Ilmu Kesehatan Anak FKUIRSCM. Prevalensi gangguan tidur pada remaja usia
12-15 tahun di sekolah lanjutan tingkat pertama. Sari Pediatri. 2009;11: 149-54.

8. Angkasa. "Over Capacity Narapidana di Lembaga Pemasyarakatan, Faktor Penyebab, Implikasi Negatif, Serta Solusi dalam Upaya Optimalisasi Pembinaan Narapidana", Jurnal Dinamika Hukum, Vol. 10 No. 3, (2010) 